\title{
Effect of Ciprofloxacin on S. aureus and E. coli Growth in Presence of Vitamin C Using Cup Cut Diffusion
} \section{Method}

\author{
Suhera M. Aburawi ${ }^{1}$, Bassma M. Doro ${ }^{2}$ and Ebtisam A. Awad ${ }^{1}$ \\ 1. Department of Pharmacology and Clinical Pharmacy, Faculty of Pharmacy, University of Tripoli. Tripoli, Libya \\ 2. Department of Microbiology and Immunology, Faculty of Pharmacy, University of Tripoli, Tripoli, Libya
}

\begin{abstract}
Ciprofloxacin is a second-generation of fluoroquinolone, broad-spectrum antibiotic with bactericidal activity against Gram-positive and Gram-negative organisms. It is one of the most widely used antibiotics, because of its efficacy, safety, and relatively low cost. Ascorbic acid (vitamin C) is water-soluble monosaccharide antioxidant; it is essentially required by the body for its various biochemical and physiological processes. S. aureus is Gram-positive cocci; widely distributed in the environment, it is a member of the normal flora of the body. S. aureus is not always pathogenic; it is a common cause of skin infections including abscesses, respiratory infections such as sinusitis, and food poisoning. E. coli is Gram-negative bacteria, found in the environment, foods, and intestines. Most E. coli strains are harmless; it is part of the normal microbiota of the gut. However, some serotypes of E. coli cause serious food poisoning in their hosts; it can cause diarrhea, while others cause urinary tract infections, respiratory illness and pneumonia, and other illnesses. Method: Cup cut diffusion method was applied. Experiment I: is carried out to choose the concentration of vitamin $\mathrm{C}$ to be used in experiment II. The negative control is normal saline, added in cup in each plate, vitamin C $(100 \mathrm{mg} / \mathrm{mL}, 200 \mathrm{mg} / \mathrm{mL}, 400$ $\mathrm{mg} / \mathrm{mL}$ ) was added, the volume in each cup was $100 \mu \mathrm{L}$. Experiment II: Eight groups of treatments were applied. The first is the negative control ( $1 \%$ normal saline), the second group is the positive control of vitamin C (200 mg/mL). The third, fourth and fifth groups are ciprofloxacin with different concentrations $(10 \mathrm{mg} / \mathrm{mL}, 20 \mathrm{mg} / \mathrm{mL}, 40 \mathrm{mg} / \mathrm{mL})$; the sixth, seventh and eighth are the combination of vitamin C with each concentration of ciprofloxacin $(10 \mathrm{mg} / \mathrm{mL}, 20 \mathrm{mg} / \mathrm{mL}, 40 \mathrm{mg} / \mathrm{mL})$. Each group includes six petri dishes. Bacterial plates were incubated at $37{ }^{\circ} \mathrm{C}$ for $24 \mathrm{~h}$ and $48 \mathrm{~h}$. Zone of inhibition is measured in mm. Results and conclusion: Ciprofloxacin produces dose dependent increase in zone of inhibition of S. aureus and E. coli growth, after 24 and 48 hours incubation. While vitamin C in the concentration used produced inhibitory effect on the growth of S. aureus and E. coli, after 24 hours incubation, vitamin $\mathrm{C}$ effect was not changed after 48 hours incubation. After 24 hours incubation, vitamin C potentiated the effect of ciprofloxacin at low concentration $(10 \mathrm{mg} / \mathrm{mL})$; while vitamin $\mathrm{C}$ antagonized the effect of ciprofloxacin at higher concentrations (20 and $40 \mathrm{mg} / \mathrm{mL})$ on $S$. aureus growth. In the same time, ciprofloxacin antagonized the inhibitory effect of vitamin C on S. aureus growth. After 48 hours incubation, $S$. aureus produced resistance against ciprofloxacin alone, and that combined with vitamin C compared to zone of inhibition after 24 hours. Ciprofloxacin produced dose dependent inhibition of E. coli growth after incubation for 24 and 48 hours. Vitamin C potentiated the inhibitory effect induced by ciprofloxacin (additive effect). The inhibitory effect of ciprofloxacin, vitamin $\mathrm{C}$ and the combination was not changed after 48 hours compared to 24 hours.
\end{abstract}

Key words: Ciprofloxacin, vitamin C, S. aureus, E. coli, cup cut diffusion method.

\section{Introduction}

Vitamin C (ascorbic acid) is water-soluble monosaccharide antioxidant. It is essential nutrient; it is required for various biochemical and physiological processes in the body. Human body is unable to

Corresponding author: Suhera M. Aburawi, PhD, professor, research fields: pharmacology and toxicology. synthesize vitamin C and obtains it from diet [1]. It is essential for the development and maintenance of connective tissues. It plays an important role in bone formation, wound healing and maintenance of healthy gums [2].

Vitamin C plays an important role in several metabolic functions including the activation of vitamin $\mathrm{B}$, folic acid, the conversion of cholesterol to bile acids 
and the conversion of amino acid, tryptophan, to neurotransmitter, as serotonin [1]. However, the significance and beneficial effect of vitamin $\mathrm{C}$ in respect to human disease such as cancer, atherosclerosis, diabetes, neurodegenerative disease and metal toxicity remains equivocal [2]. It has been shown to facilitate iron absorption by its ability to reduce ferric iron to the ferrous form [3].

Vitamin C protects DNA from damage caused by free radicals and mutagens [4]. Vitamin C has multiple effects on the development, proliferation and function of lymphocytes [5].

Ciprofloxacin is a broad-spectrum antibiotic of the semisynthetic fluoroquinolone class. It is one of the most widely used antibiotics in the world because of its efficacy, safety, and relatively low cost [6]. Ciprofloxacin is a second-generation of the fluoroquinolone, broad-spectrum antibiotic with bactericidal activity against Gram-positive and Gram-negative organisms, including those resistant to penicillin, cephalosporin, and aminoglycosides [7].

Ciprofloxacin, has two bacterial drug targets, DNA gyrase and DNA topoisomerase IV [8, 9]. DNA gyrase and DNA topoisomerase IV are enzymes that play essential roles in most nucleic acid processes; they help to control the levels of DNA under- and over-winding and remove knots and tangles from the bacterial chromosome [10-12].

DNA topoisomerases keep DNA untangled and modulate torsional stress to affect DNA replication, transcription, and, plausibly, every other aspect of DNA metabolism [13, 14] and passing DNA strands through each other involves the enzyme making double-strand DNA breaks, which is dangerous because these breaks can be highly genotoxic. Topoisomerases usually mitigate this risk by maintaining the breaks only transiently [6].

Ciprofloxacin interferes with the transient nature of the topoisomerase-induced double-strand breaks by stabilizing DNA/topoisomerase/drug ternary complex that traps the enzyme-bound double-strand breaks, thereby blocking bacterial growth "bacteriostatic" effect $[15,16]$. Ciprofloxacin treatment also increases reactive oxygen species, resulting in bacterial death, as bactericidal effect [17].

Ciprofloxacin is used for the treatment of various infectious diseases, including osteomyelitis, gonorrhea, and infections of the urinary and gastrointestinal tracts, respiratory tree, skin and soft tissues [18]. It is also effective in perianal Crohn's disease [19]. It showed excellent activity against pseudomonas infections. Acidic $\mathrm{pH}$ conditions decreased its activity [20].

Aim of work: is to study the effect of ciprofloxacin on $E$. coli and S. aureus growth in presence of vitamin $\mathrm{C}$ using cup cut diffusion method.

\section{Methodology}

Chemicals, reagents, and microorganisms: Vitamin $\mathrm{C}$ is white crystalline powder obtained from pharmaceutical industry society of Tunisia. Ciprofloxacin infusion was obtained from Doracs, Sousse, Tunisie. Muller-Hinton media, Muller-Hinton broth, and melted agar were from Oxoid-Canada. Normal saline was purchased from Riedel-deHaen, Berlin, Germany. S. aureus (ATCC 25923) and E. coli (ATCC 25922) strains were used.

Method: Strains was prepared in the lab by using $10^{8}$ $\mathrm{CFU} / \mathrm{mL}$ in Muller-Hinton broth; agar plates were swapped with overnight culture of bacteria; the plates were allowed to absorb the bacteria and cups were made by sterile standard cork borer (cup cut diffusion method) [21].

Experiment I: is carried out to choose the concentration of vitamin C to be used in experiment II. The negative control is normal saline, added in cup in each plate, vitamin C $(100 \mathrm{mg} / \mathrm{mL}, 200 \mathrm{mg} / \mathrm{mL}, 400$ $\mathrm{mg} / \mathrm{mL}$ ) was added, the volume in each cup was 100 $\mu \mathrm{L}$.

Experiment II: Negative control is normal saline, the positive control is vitamin C ( $200 \mathrm{mg} / \mathrm{mL}$ ) added in cup in each plate, Ciprofloxacin alone was added in the plate in different concentrations $(10 \mathrm{mg} / \mathrm{mL}, 20$ 
$\mathrm{mg} / \mathrm{mL}, 40 \mathrm{mg} / \mathrm{mL}$ ); vitamin C combination with each concentration of Ciprofloxacin $(10 \mathrm{mg} / \mathrm{mL}, 20 \mathrm{mg} / \mathrm{mL}$, $40 \mathrm{mg} / \mathrm{mL}$ ) was added. The volume in each cup was $100 \mu \mathrm{L}$. Bacterial plates were incubated at $37^{\circ} \mathrm{C}$ for 24 hr and $48 \mathrm{hr}$, after which the zone of inhibition diameter was measured in $\mathrm{mm}$.

\section{Results}

3.1 Effect of Vitamin $C$ on the Zone of Inhibition of $S$. aureus and E. coli

Vitamin C produces dose dependent inhibition of $S$. aureus and E. coli growth (Figs. 1 and 2).

3.2 Effect of Ciprofloxacinin in Presence of Vitamin C on $S$. aureus Growth

\subsubsection{Effect of Different Concentration of} Ciprofloxacin on S. aureus Growth after Incubation 24 Hours

Ciprofloxacin at concentration $10 \mathrm{mg} / \mathrm{mL}$ produced significant zone of inhibition less than ciprofloxacin at concentrations of $20 \mathrm{mg} / \mathrm{mL}$ and $40 \mathrm{mg} / \mathrm{mL}$ ( $p \leq$ 0.05). Ciprofloxacin at concentration $20 \mathrm{mg} / \mathrm{mL}$ increased significantly the zone of inhibition compared with $10 \mathrm{mg} / \mathrm{mL}(p \leq 0.05)$, insignificant less zone of inhibition than $40 \mathrm{mg} / \mathrm{mL}$ effect $(p>$ 0.05).

Ciprofloxacin $40 \mathrm{mg} / \mathrm{mL}$ produced zone of inhibition more than both concentrations of ciprofloxacin $10 \mathrm{mg} / \mathrm{mL}(p \leq 0.05)$ and $20 \mathrm{mg} / \mathrm{mL}(p>$ 0.05) (Table 1, Fig. 3).

3.2.2 Effect of Vitamin C and Ciprofloxacin on $S$. aureus Growth after Incubation 24 Hours

Vitamin C alone, at concentration $200 \mathrm{mg} / \mathrm{mL}$, produced clear zone of inhibition on growth of $S$. aureus. Combined treatments of ciprofloxacin at concentration $10 \mathrm{mg} / \mathrm{mL}, 20 \mathrm{mg} / \mathrm{mL}$, or $40 \mathrm{mg} / \mathrm{mL}$ with Vitamin C showed significant decrease of zone of inhibition in the growth of $S$. aureus, compared to the zone of inhibition produced by the effect of Vitamin C alone $(p \leq 0.05)$ (Table 1 , Fig. 3).

Ciprofloxacin $(10 \mathrm{mg} / \mathrm{mL})$ in combination with vitamin C produced zone of inhibition more than zone of inhibition produced by treatment with ciprofloxacin $10 \mathrm{mg} / \mathrm{mL}$ only ( $p \leq 0.05)$. While ciprofloxacin at concentrations $20 \mathrm{mg} / \mathrm{mL}$ or $40 \mathrm{mg} / \mathrm{mL}$ in combination with vitamin $\mathrm{C}$ produced decrease in zone of inhibition compared with ciprofloxacin $(20 \mathrm{mg} / \mathrm{mL}$ or $40 \mathrm{mg} / \mathrm{mL}$ ) each alone $(p \leq 0.05)$.

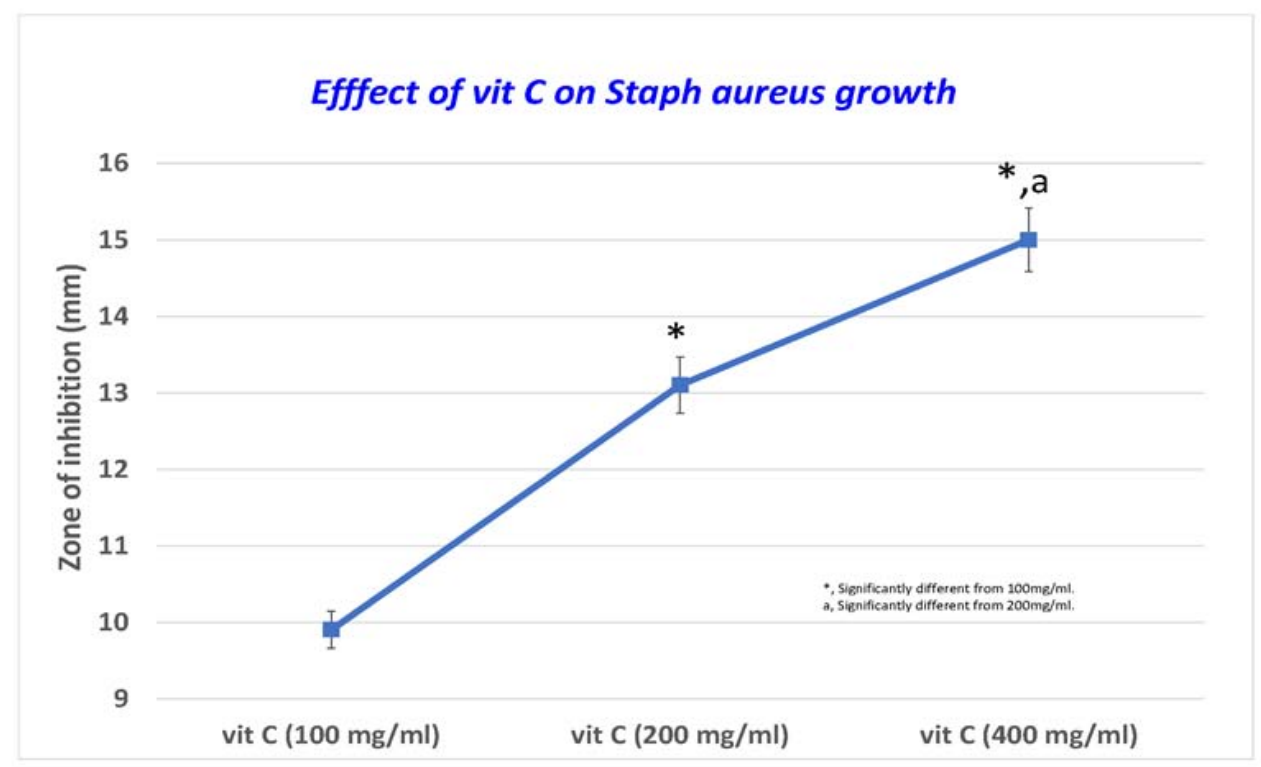

Fig. 1 Effect of vitamin $C$ on the growth of $S$. aureus using cup cut diffusion method. 


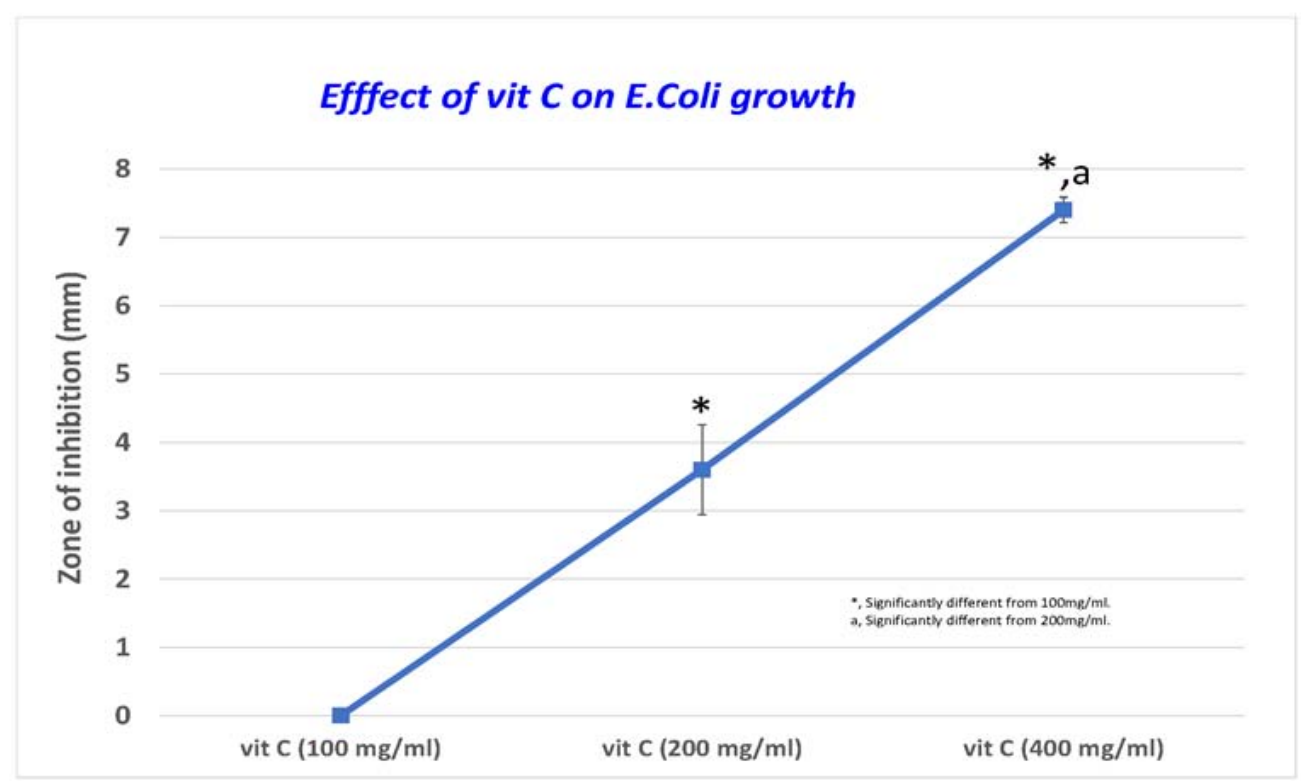

Fig. 2 Effect of vitamin $C$ on the growth of $E$. coli using cup cut diffusion method.

Table 1 Effect of ciprofloxacin on S. aureus growth in presence of Vitamin C.

\begin{tabular}{lll}
\hline Treatments & Zone of inhibition after $24 \mathrm{~h}$ & Zone of inhibition after $48 \mathrm{~h}$ \\
\hline Vitamin C $(200 \mathrm{mg} / \mathrm{mL})$ & $13.1 \pm 0.367$ & $13.1 \pm 0.367$ \\
Cipro $(10 \mathrm{mg} / \mathrm{mL})$ & $6.41 \pm 0.300^{\mathrm{a}, \mathrm{b}}$ & $00 \pm 00^{\mathrm{a}, \mathrm{b}, \mathrm{d}}$ \\
Cipro $(20 \mathrm{mg} / \mathrm{Ml})$ & $14.33 \pm 0.586$ & $10.58 \pm 0.351^{\mathrm{d}}$ \\
Cipro $(40 \mathrm{mg} / \mathrm{mL})$ & $15.25 \pm 0.281$ & $11.83 \pm 0.421^{\mathrm{a}, \mathrm{d}}$ \\
Vit C + Cipro $(10 \mathrm{mg} / \mathrm{mL})$ & $8.75 \pm 0.381^{*, \mathrm{c}}$ & $2.16 \pm 1.376^{*, \mathrm{~d}}$ \\
Vit C + Cipro $(20 \mathrm{mg} / \mathrm{mL})$ & $11.58 \pm 0.238^{*, \mathrm{a}}$ & $6.58 \pm 1.457^{*, \mathrm{a}, \mathrm{d}}$ \\
Vit C + Cipro $(40 \mathrm{mg} / \mathrm{mL})$ & $12.66 \pm 0.166^{*, \mathrm{~b}}$ & $7.66 \pm 0.459^{*, \mathrm{~b}, \mathrm{~d}}$ \\
\hline
\end{tabular}

*, significantly different compared to vitamin $\mathrm{C}$ at $p \leq 0.05$; a: significantly different compared to cipro (20 $\mathrm{mg} / \mathrm{mL})$ at $p \leq 0.05$; $\mathrm{b}$ : significantly different compared to cipro $(40 \mathrm{mg} / \mathrm{mL})$ at $p \leq 0.05$; c: significantly different compared to cipro $(10 \mathrm{mg} / \mathrm{mL})$ at $p \leq 0.05$; d: significantly different compared to the same treatment after $24 \mathrm{~h}$ at $p \leq 0.05$.

\subsubsection{Effect of Different Concentration of} Ciprofloxacin on S. aureus Growth after Incubation 48 Hours

Ciprofloxacin at concentration $10 \mathrm{mg} / \mathrm{mL}$ did not produce any inhibition effect on the growth of $S$. aureus, compared to the effect of ciprofloxacin at concentrations $20 \mathrm{mg} / \mathrm{mL}$ and $40 \mathrm{mg} / \mathrm{mL}$, which produce significant increase in zone of inhibition $(p \leq$ 0.05 ) compared with ciprofloxacin $10 \mathrm{mg} / \mathrm{mL}$ (Table 1 , Fig. 4).

Ciprofloxacin at concentration $20 \mathrm{mg} / \mathrm{mL}$ produced insignificant increase in zone of inhibition compared to the treatment with ciprofloxacin at concentration 40 $\mathrm{mg} / \mathrm{mL}(p>0.05)$.

Comparing the zone of inhibition produced by different treatment (ciprofloxacin alone or in combination with Vitamin C) after incubation for 48 hours, it was found that the zones of inhibition after 48 hours are significantly less than after 24 hours ( $p \leq$ 0.05 ). While the zone of inhibition produced by Vitamin C after 24 hours was not changed after 48 hours $(p>0.05)$ (Table 1, Figs. 4 and 5). 


\section{Effect of ciproflaxacin on staph in presence of vitC}

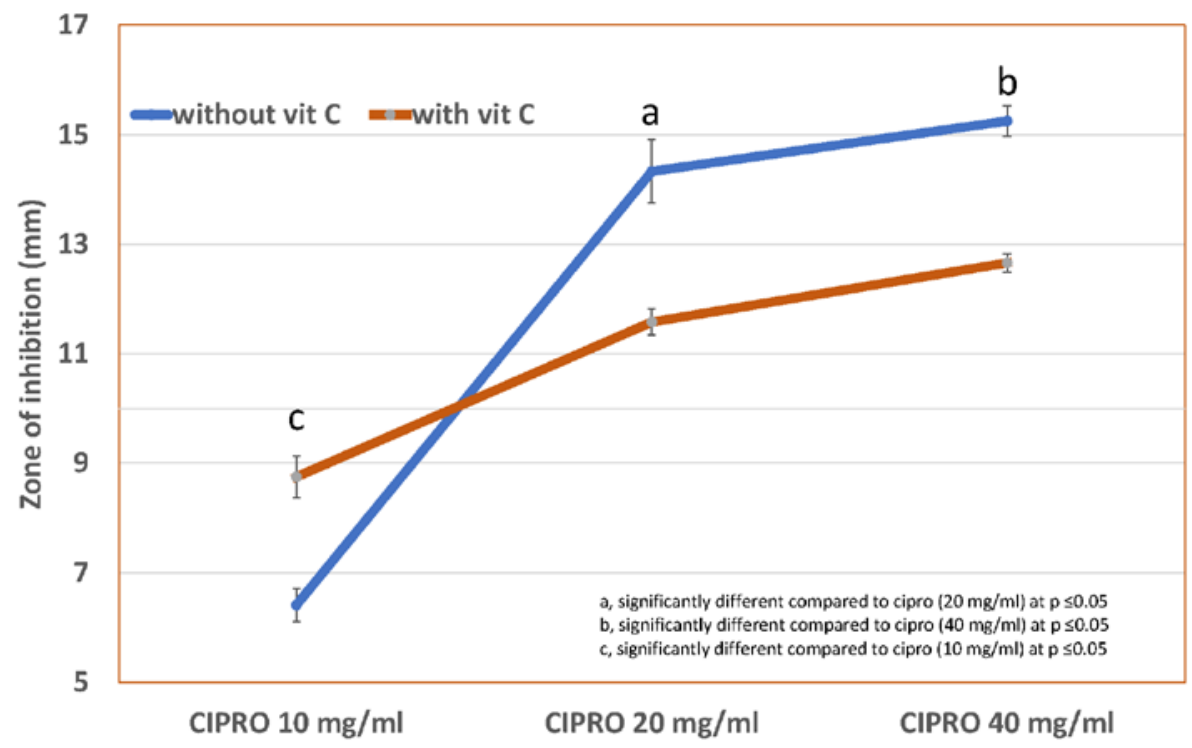

Fig. 3 Effect of ciprofloxacin on S. aureus growth in presence of Vitamin C after incubation for $24 \mathrm{~h}$.
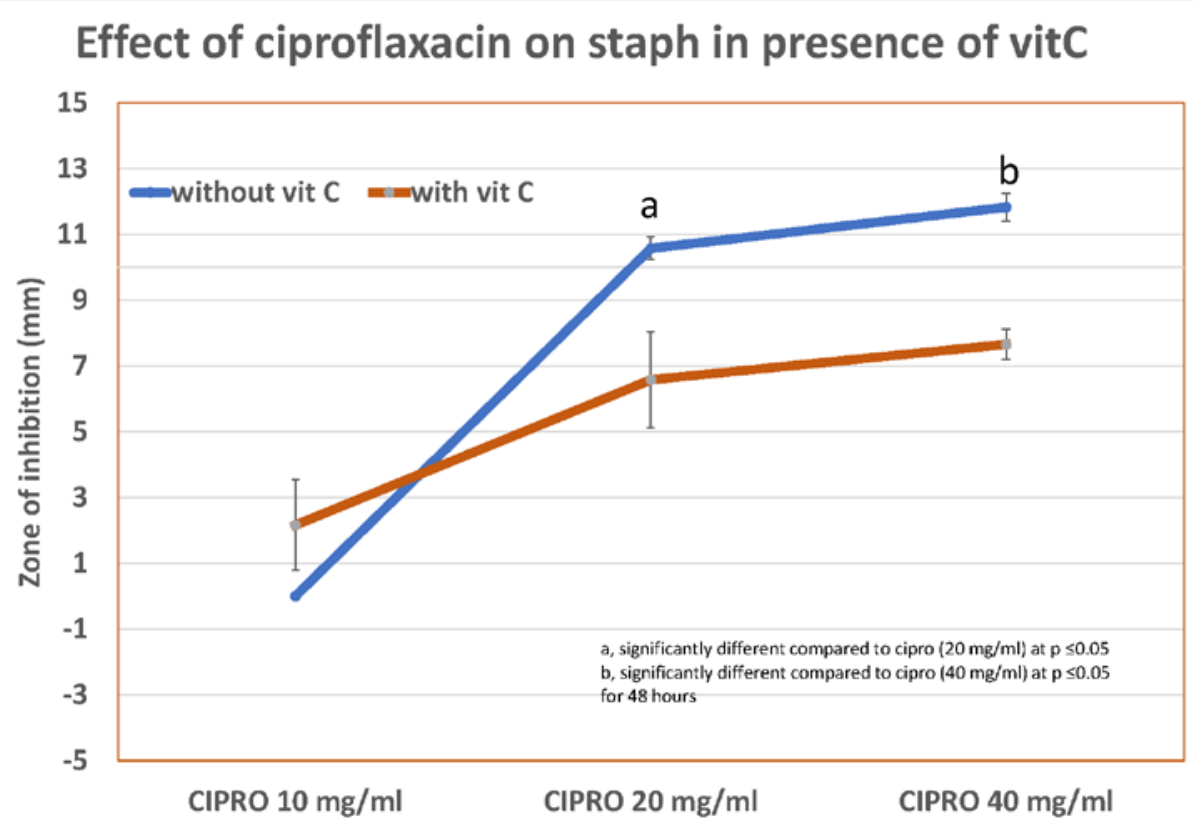

Fig. 4 Effect of ciprofloxacin on S. aureus growth in presence of Vitamin C after incubation for $48 \mathrm{~h}$. 


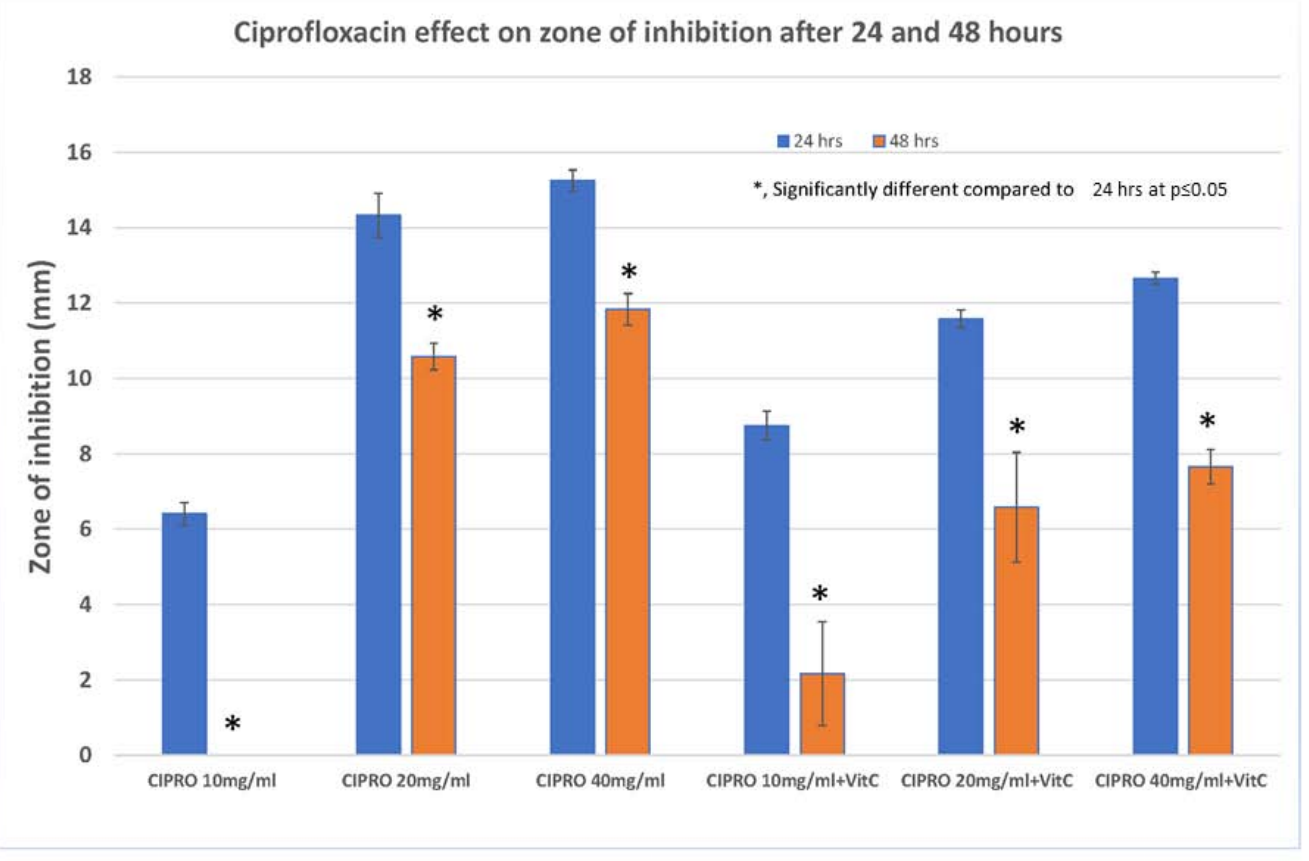

Fig. 5 Effect of ciprofloxacin on S. aureus growth in presence of Vitamin C after incubation for 24 and $48 \mathrm{~h}$.

3.3 Effect of Ciprofloxacin on E. coli Growth in Presence of Vitamin C

\subsubsection{Effect of Different Concentration of} Ciprofloxacin on E. coli Growth after Incubation 24 Hours

Ciprofloxacin at concentration $10 \mathrm{mg} / \mathrm{mL}$ produced significant increase of zone of inhibition of the growth of $E$. coli ( $p \leq 0.05$ ); by increasing the concentration of ciprofloxacin, the zone of inhibition increased significantly compared to ciprofloxacin at concentration $10 \mathrm{mg} / \mathrm{mL}(p \leq 0.05)$. Ciprofloxacin at concentration $40 \mathrm{mg} / \mathrm{mL}$ produced insignificant increase in zone of inhibition of $E$. coli growth compared to ciprofloxacin at concentration $20 \mathrm{mg} / \mathrm{mL}$ $(p>0.05)$.

\subsubsection{Effect of Ciprofloxacin on Vitamin C}

Vitamin $\mathrm{C}$ at concentration $200 \mathrm{mg} / \mathrm{mL}$ produced inhibition of $E$. coli growth.

Ciprofloxacin with the three concentrations used (10,
20, $40 \mathrm{mg} / \mathrm{mL}$ ) combined with vitamin C produced an increase of zone of inhibition of $E$. coli growth significantly compared to that produced by vitamin C alone ( $p \leq 0.05$ ) (Table 2, Fig. 6).

3.3.3 Effect of Vitamin C on Ciprofloxacin Effect of the Growth of E. coli after Incubation 24 Hours

Vitamin C did not change the zone of inhibition of $E$. coli growth, that produced by ciprofloxacin at 10 $\mathrm{mg} / \mathrm{mL}(p>0.05)$. While Vitamin C increased significantly the zone of inhibition produced by ciprofloxacin with concentrations 20 and $40 \mathrm{mg} / \mathrm{mL}$ compared to ciprofloxacin of the same concentration only; the combined treatment showed additive effect on zone of inhibition of $E$. coli growth $(p \leq 0.05)$.

The effect of Vitamin C, ciprofloxacin with different concentrations, and the combined treatments did not show any significant difference after 48 hours incubation compared to 24 hours incubation $(p>0.05)$ (Table 2). 
Table 2 Effect of ciprofloxacin on $E$. coli growth in presence of Vitamin C.

\begin{tabular}{ll}
\hline Treatments & Zone of inhibition after 24 hrs \\
\hline Vitamin C $(200 \mathrm{mg} / \mathrm{mL})$ & $3.60 \pm 0.659$ \\
Cipro $(10 \mathrm{mg} / \mathrm{mL})$ & $17.00 \pm 0.806^{*, a, b}$ \\
Cipro $(20 \mathrm{mg} / \mathrm{mL})$ & $20.33 \pm 0.654^{*}$ \\
Cipro $(40 \mathrm{mg} / \mathrm{mL})$ & $21.83 \pm 0.614^{*}$ \\
Vit C + Cipro $(10 \mathrm{mg} / \mathrm{mL})$ & $18.41 \pm 0.800^{*}$ \\
Vit C + Cipro $(20 \mathrm{mg} / \mathrm{mL})$ & $22.66 \pm 0.802^{*, \mathrm{a}}$ \\
Vit C + Cipro $(40 \mathrm{mg} / \mathrm{mL})$ & $24.33 \pm 1.308^{*, \mathrm{~b}}$ \\
\hline
\end{tabular}

*, significantly different compared to vitamin $\mathrm{C}$ at $p \leq 0.05$; a: significantly different compared to cipro (20 mg/mL) at $p \leq 0.05$; b: significantly different compared to cipro $(40 \mathrm{mg} / \mathrm{ml})$ at $p \leq 0.05$.

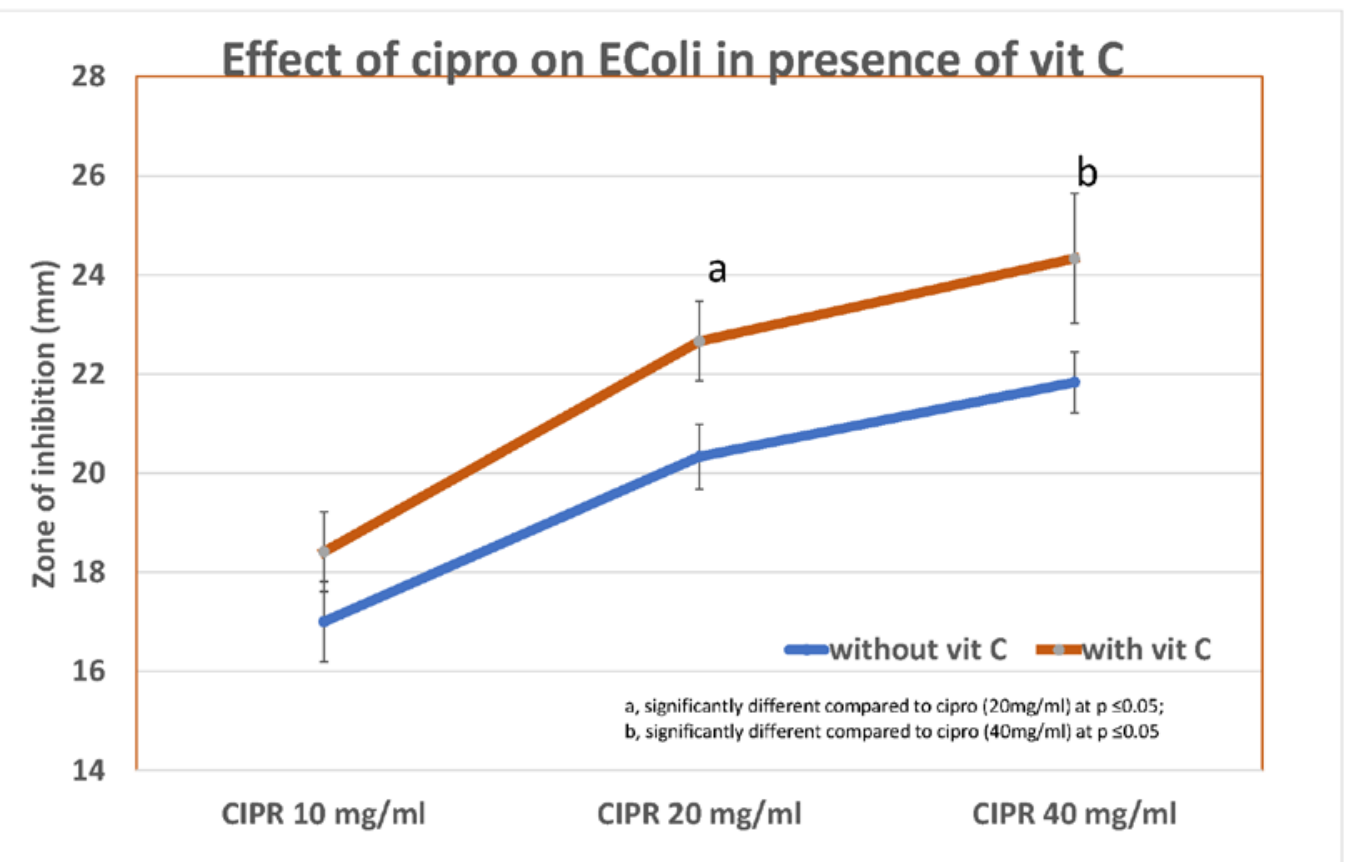

Fig. 6 Effect of ciprofloxacin on $E$. coli growth in presence of Vitamin C after incubation for $24 \mathrm{~h}$.

\section{Discussion}

Staphylococcus aureus is an important pathogenic organism causing a variety of local and systemic infections and was originally susceptible to quinolones [22]. Staphylococcus aureus is a major human pathogen that causes a wide range of clinical infections. It may cause bacteremia, infective endocarditis, osteoarticular, or skin and soft tissue infections [23].

Most strains of E. coli are not harmful but are part of the healthful bacterial flora in the human gut. However, some types can cause illness in humans. Some strains produce the most powerful toxins that cause an intestinal infection. Other types of $E$. coli infection can lead to urinary tract infections, respiratory illness, pneumonia, and other illnesses like meningitis [24].

4.1 Effect of Vitamin C on S. aureus and E. coli Growth

Vitamin C showed dose dependent inhibitory effect on the growth of $S$. aureus and E. coli. This effect confirms previous research [21, 25]. The acidity of vitamin C plays an important role in contributing to the inhibition of S. aureus growth; also, vitamin C affects the metabolism of $S$. aureus leading to the growth inhibition observed [26]. 
Vitamin C alters the cell surface function, increasing the permeability of Gram-negative bacteria to antibiotics [27, 28]. Vitamin C acts on E. coli by reducing the biosynthesis of extracellular polymer substances, especially the polysaccharide component of the matrix. Once the extracellular polymer substances content is reduced, then the bacterial cells are fully exposed to the external medium resulting in that the cells are more susceptible to killing, either by vitamin C-induced oxidative stress, or by other antimicrobials agents [29].

\subsection{Effect of Ciprofloxacin on S. aureus Growth in Presence of Vitamin C}

In this study, after incubation of $S$. aureus for 24 hours, ciprofloxacin alone at concentration (10, 20 and $40 \mathrm{mg} / \mathrm{mL}$ ) used produced significant dose dependent effect in inactivating $S$. aureus respectively; as was observed by Craig [30] who obtained dose dependent inhibitory effect.

Since their introduction, ciprofloxacin blocks the growth of bacteria by inhibition DNA gyrase of bacteria [8, 9] and has bacteriostatic effect [15, 16], and also shows bactericidal effect [17].

The combination of vitamin $\mathrm{C}$ with ciprofloxacin with concentrations of 20 and $40 \mathrm{mg} / \mathrm{mL}$, produced significant decrease of the activity of ciprofloxacin, compared to ciprofloxacin when used alone. This is indicating that vitamin $\mathrm{C}$ antagonized the inhibitory effect of ciprofloxacin against $S$. aureus growth. This effect was not observed when low concentration of ciprofloxacin $(10 \mathrm{mg} / \mathrm{mL})$ was used.

Also, it was observed that when combined vitamin C with all concentrations of ciprofloxacin $(10,20,40$ $\mathrm{mg} / \mathrm{mL}$ ), significant decrease of the activity of vitamin $\mathrm{C}$ was produced compared with the inhibitory effect of vitamin $\mathrm{C}$ alone against $\mathrm{S}$. aureus growth.

One of the mechanisms of ciprofloxacin is increasing reactive oxygen species, leading to bacterial cell death (bactericidal) [17]; vitamin $\mathrm{C}$ as antioxidants interferes with ciprofloxacin through scavenging the reactive oxygen species produced by ciprofloxacin. Therefore, vitamin C antagonized the inhibitory effect of ciprofloxacin on S. aureus growth [31]. The production of free radical by ciprofloxacin may antagonize the free radical scavenging effect of vitamin $\mathrm{C}$; as a result, ciprofloxacin may antagonize vitamin C effect on $S$. aureus growth inhibition.

Combined treatment of vitamin $\mathrm{C}$ with ciprofloxacin at low concentration $(10 \mathrm{mg} / \mathrm{mL})$, increased the inhibitory effect on $S$. aureus growth compared to the inhibitory effect of ciprofloxacin alone. The acidity of vitamin C contributes to the inhibition of $S$. aureus growth; also, it affects the metabolism of $S$. aureus and that these changes are likely to result in the observed growth inhibition [26] and potentiate ciprofloxacin action.

The combined treatment of vitamin $\mathrm{C}$ and ciprofloxacin with low concentration $(10 \mathrm{mg} / \mathrm{mL})$ produced zone of inhibition of $S$. aureus growth higher than ciprofloxacin alone significantly, but less than the additive effect; this indicates that vitamin $\mathrm{C}$ antagonized the weak effect of ciprofloxacin as explained above. In addition, it could be explained that the ciprofloxacin low concentration $(10 \mathrm{mg} / \mathrm{mL})$ could be sub-therapeutic concentration in producing reactive oxygen species; therefore, the inhibitory effect of vitamin $\mathrm{C}$ was observed only.

Ciprofloxacin with all concentrations $(10 \mathrm{mg} / \mathrm{mL}$, $20 \mathrm{mg} / \mathrm{mL}, 40 \mathrm{mg} / \mathrm{mL}$ ), and in combination with vitamin C, after incubation for 48 hours, produced significant reduction of inhibitory effect on $S$. aureus growth compared to the inhibitory effect after 24 hours. $S$. aureus produced resistance to ciprofloxacin when used alone or in combination with vitamin C, during the last 24 hours of incubation.

S. aureus resistance to quinolone is primarily mediated through chromosomal point mutations in gyr $A$ and gyr $B$ (encoding subunits of DNA gyrase) and $g r l$ $A$ and $\operatorname{grl} B$ (encoding subunits of topoisomerase IV) [22, 32]; together, this comprises the so-called quinolone-resistance-determining regions (QRDRs). 
Amino acid changes in these critical regions of the enzyme-DNA complex (QRDR), reduce quinolone affinity for both of its targets, additionally nor $A$ gene (encodes quinolone efflux pump) contributing to reduced susceptibility [33]. DNA sequence analysis revealed that ciprofloxacin resistance by $S$. aureus is associated with Ser-84 $\rightarrow$ Phe mutation in the DNA gyrase A protein [34].

Therefore, drug-enzyme binding is reduced, and quinolones loss their ability to inhibit DNA ligation or to reduce the stability of the enzyme-quinolone-DNA complex [35-41].

Effect of vitamin C on S. aureus in combination with ciprofloxacin showed that Vitamin $\mathrm{C}$ decreased the effect of ciprofloxacin by scavenging the reactive oxygen species produced ciprofloxacin. However, when used alone vitamin $\mathrm{C}$ significantly inhibited the growth of $S$. aureus.

\subsection{Effect of Ciprofloxacin on E. Coli Growth in Presence of Vitamin $C$}

Ciprofloxacin (40 mg/mL, $20 \mathrm{mg} / \mathrm{mL}, 10 \mathrm{mg} / \mathrm{mL}$ ) inhibitory effect on $E$. coli growth after incubation for 24 hours, showed dose dependent inhibition of E. coli growth. This indicates that increasing the concentration of ciprofloxacin, results in a significant increase in inhibitory effect on growth of $E$. coli.

Ciprofloxacin produced concentration dependence $E$. coli killing [30]. E. coli is more sensitive to ciprofloxacin than S. aureus; this may be due to physiological differences of bacterial species [21]. Gram-negative bacterium regulates outer membrane permeability characteristics by the presence of hydrophilic channels known as porins. Fluoroquinolones enter E. coli bacterial cell both by crossing the membranes and by accessing the porins [42].

The combination of vitamin $\mathrm{C}$ with low concentration of ciprofloxacin $(10 \mathrm{mg} / \mathrm{mL})$ did not change the inhibitory effect on $E$. coli growth compared to ciprofloxacin alone. While vitamin C combined with higher concentration of ciprofloxacin (20 and $40 \mathrm{mg} / \mathrm{mL}$ ), produced an increase in the inhibitory effect on the growth of E. coli, compared to the effect of ciprofloxacin each alone. This indicates that vitamin $C$ potentiates ciprofloxacin effect on $E$. coli growth, or it may produce additive inhibitory effect.

Vitamin C produced slightly inhibitory effect on $E$. coli growth when used alone, but when combined with antibacterial or others antioxidants produced clear inhibitory effect. This may due to the effect of vitamin $C$ on growth of $E$. coli by reducing biosynthesis of extracellular polymer substances, especially the polysaccharide component of the matrix; therefore, once the extracellular polymer substances content is reduced, then the bacterial cells are more exposed to external medium and more susceptible to killing [29]. Vitamin C enhanced the effect of ciprofloxacin, by increasing the permeability of Gram-negative bacteria to its effect [21, 27, 28].

It was reported that Vitamin $\mathrm{C}$ potentiated the antibacterial activity of ciprofloxacin, this may be due to its pro-oxidant activity or by altering the membrane permeability [43].

The inhibitory effect of ciprofloxacin with or without vitamin $\mathrm{C}$ on $E$. coli growth was not changed after 48 hours incubation compared to 24 hours incubation.

S. aureus produced resistance by many mechanisms of ciprofloxacin (significant decrease of activity) in presence or absence of vitamin C, but $E$.coli does not produce resistance to ciprofloxacin compared with $S$. aureus. It was more susceptible of ciprofloxacin, vitamin $\mathrm{C}$ in combination with ciprofloxacin enhanced effectiveness of ciprofloxacin; because vitamin $\mathrm{C}$ increased permeability of Gram negative bacteria to antibiotics and also competing with magnesium binding site in the cell wall, and cell membrane [21].

\section{Conclusions}

Ciprofloxacin produces dose dependent increase in 
zone of inhibition of $S$. aureus and $E$. coli growth, after 24 and 48 hours incubation. While vitamin $C$ in the concentration used produced inhibitory effect on the growth of S. aureus and E. coli, after 24 hours incubation, vitamin $\mathrm{C}$ effect was not changed after 48 hours incubation.

After 24 hours incubation, vitamin $C$ potentiated the effect of ciprofloxacin at concentration $10 \mathrm{mg} / \mathrm{mL}$; while vitamin $\mathrm{C}$ antagonized the effect of ciprofloxacin at higher concentrations 20 and $40 \mathrm{mg} / \mathrm{mL}$ on $S$. aureus growth.

After 48 hours incubation, S. aureus produced resistance against ciprofloxacin alone, and combined with vitamin C compared to zone of inhibition after 24 hours.

Ciprofloxacin produced dose dependent inhibition of $E$. coli growth after incubation for 24 and 48 hours. Vitamin C potentiated the inhibitory effect induced by ciprofloxacin (additive effect).

The inhibitory effect of ciprofloxacin, vitamin $\mathrm{C}$ and the combination on $E$. coli growth was not changed after 48 hours compared to 24 hours.

Ciprofloxacin in more variable concentration with vitamin $\mathrm{C}$ should be studied in details to find out an explanation for the behavior we obtained. In vivo experiment should be carried out for vitamin $\mathrm{C}$ with other antimicrobial agents that have different mechanisms.

\section{References}

[1] Iqbal, K., Khan, A., Muzaffar, M., and Khattak, A. K. 2004. "Biological Significance of Ascorbic Acid (Vitamin C) in Human Health-A Review." Pakistan Journal of Nutrition 3 (1): 5-13.

[2] Chambial, S., Dwivedi, S., and Sharma, P. 2013. "Vitamin $\mathrm{C}$ in Disease Prevention and Cure: An Overview.” Indian J Clin Biochem 28 (4): 314-28.

[3] Sayers, M. H., Lynch, S. R., and Jocobs, P. 1973. "The Effects of Ascorbic acid Supplementation on the Absorption of Iron in Maize, Wheat and Soya.” Br. J. Haematology 24: 209-18.

[4] Du, J., Cullen, J. J., and Buettner, G. R. 2012. "Review Ascorbic Acid: Chemistry, Biology and the Treatment of Cancer.” Biochim. Biophy. Acta 18: 443-57.
[5] Van Gorkom, G. N. Y., Klein Wolterink, R. G. J., Van Elssen, C. H. M. J., Wieten, L., Germeraad, W. T. V., and Bos, G. M. J. 2018. "Influence of Vitamin C on Lymphocytes: An Overview.” Antioxidants 7 (3): 41.

[6] Conley, Z. C., Bodine, T. J., Chou, A., and Zechiedrich, L. 2018. "Wicked: The Untold Story of Ciprofloxacin.” PLoS Pathog 14 (3): e1006805.

[7] Koestner, J. A. 1989. "Ciprofloxacin: A New Fluoroquinolone.” Am J Med Sci 297 (2): 128-31.

[8] Kreuzer, K. N., and Cozzarelli, N. R. 1979. "Escherichia coli Mutants Thermosensitive for Deoxyribonucleic Acid Gyrase Subunit A: Effects on Deoxyribonucleic Acid Replication, Transcription, and Bacteriophage Growth.” J. Bacteriol. 140: 424-35.

[9] Khodursky, A. B., Zechiedrich, E. L., and Cozzarelli, N. R. 1995. “Topoisomerase IV Is a Target of Quinolones in Escherichia coli.” Proc Natl Acad Sci 92: 11801-5.

[10] Levine, C., Hiasa, H., and Marians, K. J. 1998. "DNA Gyrase and Topoisomerase IV: Biochemical Activities, Physiological Roles during Chromosome Replication, and Drug Sensitivities.” Biochim. Biophys; Acta 1400: 29-43.

[11] Anderson, V. E., and Osheroff, N. 2001. "Type II Topoisomerases as Targets for Quinolone Antibacterials.” Curr. Pharm 7: 337-53.

[12] Gentry, A. C., and Osheroff, N. 2013. "DNA Topoisomerases: Type II.” In Encyclopedia of Biological Chemistry, Amsterdam: Elsevier Inc., pp. 163-8.

[13] Fogg, J. M., Randall, G. L., Pettitt, B. M., Sumners, D. W. L., Harris, S. A., and Zechiedrich, L. 2012. "Bullied No More: When and How DNA Shoves Proteins Around." Q. Rev. Biophys. 45: 257-99.

[14] Bush, N. G., Evans, R. K., and Maxwell, A. 2015. "DNA Topoisomerases.” Eco. Sal. Plus 6ESP-0010-2014.

[15] Heisig, P. 2009. “Type II Topoisomerases Đinhibitors, Repair Mechanisms and Mutations.” Mutagenesis 24: 465-9.

[16] Aldred, K. J., Kerns, R. J., and Osheroff, N. 2014. "Mechanism of Quinolone Action and Resistance." Biochemistry (Mosc) 53: 1565-74.

[17] Zhao, X., Hong, Y., and Drlica, K. 2015. "Moving forward with Reactive Oxygen Species Involvement in Antimicrobial Lethality.” J. Antimicrob. Chemother. 70: 639-42.

[18] Sanders, W. E. Jr. 1988. "Efficacy, Safety, and Potential Economic Benefits of Oral Ciprofloxacin in the Treatment of Infections.” Rev. Infect. Dis. 10 (3): 528-43.

[19] West, R. L., Vander, W. C. J., Hansen, B. E., Felt-Bersma, R. J. F., van Tilburg, A. J. P., Drapers, J. A. G., and Kuipers, E. J. 2004. "Clinical and Endosonographic Effect of Ciprofloxacin on the Treatment of Perianal Fistulae in Crohn's Disease with Infliximab: A Double-Blind Placebo-Controlled Study.” Aliment. Pharmacol. Ther. 20: 
1329-36.

[20] Zeiler, H. J., and Grohe, K. 1986. "The in Vitro and in Vivo Activity of Ciprofloxacin.” In Ciprofloxacin. Current Topics in Infectious Diseases and Clinical Microbiology, edited by H. C. Neu, and D. S. Reeves, vol. 1. Wiesbaden: Vieweg + Teubner Verlag.

[21] Aburawi, S. M., Elahmer, N. M., Eltaif, N. F., Altubuly, R. A., and Sufya, N. M. 2013. "Effect of Vitamin C on Penicillin G Efficacy to Inhibit Bacterial Populations.” Tripolitania Medical Journal 2 (2): 44-9.

[22] Ito, H., Yoshida, H., Bogaki, S. M., Niga, T., Hattori, H., and Nakamura, S. 1994. "Quinolone Resistance Mutations in DNA Gyrase gyr A and gyr B Genes of Staphylococcus aureus." Antimicrobial Agents and Chemotherapy 38: 2014-23.

[23] Tong, S. Y. C., Davis, J. S., Eichenberger, E., Holland, T. L., and Fowler, V. 2015. "Staphylococcus Aureus Infections: Epidemiology, Pathophysiology, Clinical Manifestations, and Management.” ClinMicrobiol Rev. 28 (3): 603-61. doi: 10.1128/CMR.00134-14.

[24] Nordqvist,C. 2017. "E. coli Infection: Symptoms, Causes, and Treatment.” Last updated Mon 11 December 2017. Reviewed by Suzanne Falck, MD, FACP. https://www.medicalnewstoday.com/articles/68511.php.

[25] Ravikumar, V., Abdel-Haleem, A., Derouiche, A., Mokkapati, M. K., Gojobori, T., and Gao, X. 2017. "Low Concentrations of Vitamin C Reduce the Synthesis of Extracellular Ploymeras and Destabilize Bacteria Biofilms.” Front. Microbiol. 82599.

[26] Kallio, J., Jaakkola, M., Mäki, M., Kilpeläinen, P., and Virtanen, V. 2012. "Vitamin C Inhibits Staphylococcus Aureus Growth and Enhances the Inhibitory Effect of Quercetinon Growth of Eschrichia coli in Vitro.” Planta Med. 78 (17): 1824-30.

[27] Flora, S. J., Pande, M., and Mehta, A. 2003. "Beneficial Effect of Combined Administration of Some Naturally Occurring Antioxidants (Vitamins) and Thiol Chelators in the Treatment of Chronic Lead Intoxication.” Chem. Biol. Interact. 145: 267-80.

[28] Nikaido, H. 2003. "Molecular Basics of Bacterial Outer Membrane Permeability Revisited.” Microbiol. Mol. Biol. Rev. 4: 593-656.

[29] Pandit, S., Ravikumar, V., Abdel-Haleem, A. M., Derouiche, A., Mokkapati, V. R. S. S., Sihlbom, C., Mineta, K., Gojobori, T., Gao, X., Westerlund, F., and Mijakovic, I. 2017. "Low Concentrations of Vitamin C Reduce the Synthesis of Extracellular Polymers and Destabilize Bacterial Biofilms." Front. Microbiol. 8: 2599.

[30] Craig, W. 1993. "Pharmacodynamics of Antimicrobial Agents as a Basis for Determining Dosage Regimens.” Eur. J. Clin. Microbiol. Infect. Dis. 12 (1): 6-8.
[31] Masadeh, M. M., Alzoubi, K. H., Al-Azzam, S. I., Khabour, O. F., and Al-Buhairan, A. M. 2016. "Ciprofloxacin-Induced Antibacterial Activity Is Atteneuated by Pretreatment with Antioxidant Agents." Pathogens 5 (1): 28.

[32] Yamagishi, J., Kojima, T., Oyamada, Y., Fujimoto, K., Hattori, H., Nakumara, S., et al. 1996. "Alteration in the DNA topoisomerase IV GRL A Gene Responsible for Quinolone Resistance in Staphylococcus Aureus.” Antimicrobial Agents and Chemotherapy 40: 1157-63.

[33] Yoshida, H., Bogaki, M., Nakamura, S., Ubukata, K., and Konno, M. 1990. "Nucleotide Sequence and Characterization of the Staphylococcus Aureus nor A Gene, Which Confers Resistance to Quinolones.” Journal of Bacteriology 172: 6942-9.

[34] Sreedharan, S., Peterson, L. R., and Fisher, L. M. 1991. "Ciprofloxacin Resistance in Coagulase-Positive and -Negative Staphylococci: Role of Mutations at Serine 84 in the DNA Gyrase A Protein of Staphylococcus aureus and Staphylococcus epidermidis.” Antimicrobial Agents and Chemotherapy 35 (10): 2151-4.

[35] Aldred, K. J., McPherson, S. A., Wang, P., Kerns, R. J., Graves, D. E., Turnbough, C. L., and Jr Osheroff, N. 2012. "Drug Interactions with Bacillus anthracis Topoisomerase IV: Biochemical Basis for Quinolone Action and Resistance.” Biochemistry 51: 370-81.

[36] Aldred, K. J., McPherson, S. A., Turnbough, C. L., Jr, Kerns, R. J., and Osheroff, N. 2013. “Topoisomerase IV-Quinolone Interactions Are Mediated through a Water-Metal Ion Bridge: Mechanistic Basis of Quinolone Resistance.” Nucleic Acids Res. 41: 4628-39.

[37] Anderson, V. E., Zaniewski, R. P., Kaczmarek, F. S., Gootz, T. D., and Osheroff, N. 2000. "Action of Quinolones against Staphylococcus aureus Topoisomerase IV: Basis for DNA Cleavage Enhancement.” Biochemistry 39: 2726-32.

[38] Willmott, C. J., and Maxwell, A. 1993. "A Single Point Mutation in the DNA Gyrase A Protein Greatly Reduces Binding of Fluoroquinolones to the Gyrase-DNA Complex." Antimicrobial Agents and Chemotherapy 37: 126-7.

[39] Anderson, V. E., Gootz, T. D., and Osheroff, N. 1998. "Topoisomerase IV Catalysis and the Mechanism of Quinolone Action.” J. Biol. Chem. 273: 17879-85.

[40] Anderson, V. E., Zaniewski, R. P., Kaczmarek, F., Gootz, T. D., and Osheroff, N. 1999. "Quinolones Inhibit DNA Relegation Mediated by Staphylococcus Aureus Topoisomerase IV: Changes in Drug Mechanism across Evolutionary Boundaries.” J. Biol. Chem. 274: 35927-32.

[41] Barnard, F. M., and Maxwell, A. 2001. "Interaction between DNA Gyrase and Quinolones: Effects of Alanine Mutations at GyrA Subunit Residues Ser(83) and Asp(87).” 
Antimicrobial Agents and Chemotherapy 45: 1994-2000.

[42] Delcour, A. H. 2008. "Outer Membrane Permeability and Antibiotic Resistance.” Biochim. Biophys. Acta 1794: 808-16.

[43] Srividya, G., Deepthi, B., and Lakshminarasaiah, S. 2017.
“Ascorbic Acid Enhances Ciprofloxacin Antibacterial Activity in Vitro against Isolates of Escherichia coli from Subclinical Mastitis Cases of Buffaloes.” International Journal of Veterinary Sciences and Animal Husbandry 2 (5): 21-4. 